\title{
Social management of the elderly education system: case of Russia
}

\section{Gestão social do sistema educacional de idosos: o caso da Rússia}

\section{Gestión social del sistema educativo de personas mayores: caso de Rusia}

\author{
Gennadii G. Sorokin ${ }^{1}$ (D) \\ ${ }^{1}$ Department of Business Informatics and Mathematics, Industrial University of Tyumen, Tyumen, 625000, Russia. \\ Corresponding author: \\ Gennadii G. Sorokin \\ Email: sgenall@yandex.ru \\ How to cite: Sorokin, G. G. (2021). Social management of the elderly education system: case of Russia. Revista Tempos \\ e Espaços em Educação, 14(33), e16687. http://dx.doi.org/10.20952/revtee.v14i33.16687
}

\begin{abstract}
In the context of population ageing, it is expedient for the state to manage the national systems of elderly education. The current article studies the management issues of elderly education programs. Using the case of Russia, it addresses the elderly education projects implemented in four main forms: clubs, lecture courses, educational courses and third age universities. The specific features of each form make it optimal to perform a certain range of educational tasks. The benchmark of the elderly education practices allowed us to identify the classification attributes of the organization forms of educational programs, outline the typology of these forms and determine the scope of their application. The research results show that the form in which the project is implemented is largely determined by the type of organization on the basis of which it operates. The focus area and the main social function of the project's parent organization significantly affect the effectiveness of educational programs. The paper substantiates that it is feasible to distribute the tasks of elderly education between various agents considering the specifics of their activities and priority forms of educational projects implementation. To do so, the research proposes a management principle for differentiating the functions of the elderly education system. The paper presents recommendations for optimizing the mechanisms for managing the elderly education system and increasing its performance, which can be of use to public authorities.

Keywords: Educational programs. Elderly education system. Elderly education. Population ageing. Social management.

\section{RESUMO}

No contexto de envelhecimento populacional, é conveniente que o estado gerencie os sistemas nacionais de educação do idoso. O presente artigo estuda as questões de gestão de programas de educação de idosos. Usando o caso da Rússia, aborda os projetos de educação de idosos
\end{abstract}


implementados em quatro formas principais: clubes, cursos de palestras, cursos educacionais e universidades da terceira idade. As características específicas de cada formulário tornam-no ideal para executar uma certa gama de tarefas educacionais. O referencial das práticas de educação de idosos permitiu-nos identificar os atributos de classificação das formas de organização dos programas educativos, delinear a tipologia dessas formas e determinar o âmbito da sua aplicação. Os resultados da pesquisa mostram que a forma como o projeto é implementado é amplamente determinada pelo tipo de organização com base na qual opera. A área de foco e a principal função social da organização controladora do projeto afetam significativamente a eficácia dos programas educacionais. $\mathrm{O}$ artigo comprova que é possível distribuir as tarefas da educação do idoso entre os diversos agentes, considerando as especificidades de suas atividades e as formas prioritárias de implementação de projetos educacionais. Para tanto, a pesquisa propõe um princípio gerencial para diferenciar as funções do sistema de ensino de idosos. O artigo apresenta recomendações para otimizar os mecanismos de gestão do sistema de educação de idosos e aumentar o seu desempenho, que podem ser úteis ao poder público.

Palavras-chave: Educação de idosos. Envelhecimento da população. Gestão social. Programas educacionais. Sistema de educação de idosos.

\section{RESUMEN}

En el contexto del envejecimiento de la población, conviene que el Estado gestione los sistemas nacionales de educación de las personas mayores. El artículo actual estudia los problemas de gestión de los programas de educación para personas mayores. Usando el caso de Rusia, aborda los proyectos de educación para personas mayores implementados en cuatro formas principales: clubes, cursos de conferencias, cursos educativos y universidades de la tercera edad. Las características específicas de cada formulario lo hacen óptimo para realizar una determinada gama de tareas educativas. El punto de referencia de las prácticas educativas de personas mayores permitió identificar los atributos de clasificación de las formas de organización de los programas educativos, delinear la tipología de estas formas y determinar el alcance de su aplicación. Los resultados de la investigación muestran que la forma en que se implementa el proyecto está determinada en gran medida por el tipo de organización sobre la base de la cual opera. El área de enfoque y la función social principal de la organización matriz del proyecto afectan significativamente la efectividad de los programas educativos. El trabajo fundamenta que es factible distribuir las tareas de educación de personas mayores entre varios agentes considerando la especificidad de sus actividades y formas prioritarias de implementación de proyectos educativos. Para ello, la investigación propone un principio de gestión para diferenciar las funciones del sistema educativo de personas mayores. El trabajo presenta recomendaciones para optimizar los mecanismos de gestión del sistema educativo de personas mayores y mejorar su desempeño, que pueden ser de utilidad para las autoridades públicas.

Palabras clave: Educación de ancianos. Envejecimiento de la población. Gestión social. Programas educativos. Sistema de educación para personas mayores.

\section{INTRODUCTION}

In the context of global population aging, researchers increasingly regard the economic, social and cultural potential of the older generation as a substantial resource for modernizing various spheres of society and adapting it to new demographic realities. In the light of this, the issue of elderly education is becoming especially topical. A lack of up-to-date knowledge and social barriers faced when gaining it are the central challenges that seniors have to deal with in order to integrate and adapt to the changing environment.

Improving older people's educational level is a necessary condition for renewing their potential. A comprehensive approach should be employed to resolve the issue of mass education 
for the elderly. In particular, there is a need for specialized educational programs and a system of institutions focused exclusively on educating people of the third age. It also seems expedient to attract resources and capabilities of the existing institutions. For example, in the USA, the public school system is actively involved in tackling this problem. Public schools train over 23 million Americans aged 50+ every year (Lapshina, 2007).

An alternative structure capable of taking on a significant portion of the burden associated with training the elderly is a set of non-formal education projects. In Russia, the elderly education programs have been implemented since the 1990s. Currently, there are more than 250 ongoing projects that enroll about 100,000 students every year (Sorokin, 2020). Throughout its history, elderly education in Russia has evolved independently, and at the moment it is not directly regulated by the state. Therefore, in order to realize its potential within the social management practice, it is necessary to formulate management principles, technologies and methods that the state can use to exert a centralized influence on this system. Thus, the purpose of the research is to theoretically substantiate whether it is feasible to implement the principle of distribution of the elderly education system's functions.

\section{LITERATURE REVIEW}

Until recently, research publications have looked at aging of the world's population gathering pace as an indisputable achievement of human civilization. It was attributed to an increase in the standard of living, medical advancements, the falling number of victims in armed conflicts, etc. Nowadays, there is no consensus about the nature of the demographic megatrend, as well as its results. For instance, Eakin and Witten (2018) and Taziev (2015) highlight social and economic risks associated with the transformations of society's age structure, and view popukation aging as one of the global challenges of our time.

The global trends in population aging are echoed in the Russian society. In 2019, the share of Russia's population over 60 years was $21 \%$ (Russia in Numbers, 2019). Transformations of the age structure place additional burden on social security, the pension system and healthcare. An increase in the demographic burden shouldered by working citizens is gradually leading to dysfunctions of economic institutions.

In recent decades, the Russian government has taken a number of actions to counter these negative consequences. The measures are mainly associated with raising taxes, attracting untapped labor resources (the unemployed, women, etc.), and stimulating the migration inflow. The most radical measure was the increase in the retirement age. The effectiveness of the mechanisms currently implemented in Russia is assessed by Gelman (2019), Chahrak and Ugryniuk (2016), Savinov, Bistyaykina and Solovyova (2018), and Kalyugina et al. (2018). The researchers conclude that all the existing strategies aimed at adapting society to demographic shifts are designed not so much to handle urgent social problems as to delay dealing with them. The scholars stress that it is critical to make sure that the sets of measures for adapting society to the new demographic realities cover actions on updating and realizing seniors' potential. At that, educational programs for the elderly occupy a crucial role in this process.

The problems and development trends in elderly education in Russia are analyzed by Freydkina (2017), Ambarova and Zborovsky (2019), Smirnova (2008), Mosina and Gonezhuk (2019), and Kononygina (2006). They underline a steady increase in the number of specialized educational projects and their participants. Researchers positively assess the prospects for the development of the Russian elderly education system. At the same time, there is a range of factors impeding the development of educational practices for the senior citizens, such as a lack of the government's attention to the problems of elderly education, insecure funding, and a significant effect of negative stereotypes on seniors' ability to learn (Elyutina \& Chekanova, 2003). 
Despite the fact that most scientists support the idea of attracting the resources of the elderly education projects, the phenomenon of elderly education has not yet been studied from the perspective of sociology of management. There are extremely scarce and fragmented works on elderly education systems as objects of managerial influence in Russia. Lack of necessary empirical data poses a major barrier. For the same reason, it seems impossible to draw up an integral strategy for managing the education of senior citizens across the country. The abovementioned circumstances emphasize the relevance of studying various aspects of the elderly education system management in Russia.

\section{METHODOLOGY}

The paper is based on the results of the author's studies conducted in the period from 2006 to 2019.

The first research aimed to explore the activities of elderly education projects implemented in Russia. The data for the research were derived from the interviews with organizers and teachers engaged in the elderly education projects. In total, 254 organizations from 193 localities were examined. The study scrutinized the organizational forms of the educational projects, their focus areas, funding mechanisms, and the specifics of studying at an advanced age. The primary purpose was to recognize and assess the potential of the elderly education system as a tool for managing urgent problems in society. The empirical data were processed using SPSS software package.

The second research investigated the opportunities and prospects for managing the national network of education for older adults in Russia. Through online survey, we interviewed 15 experts working in related fields: gerontologists, doctors, demographers, economists, sociologists, psychologists, physiologists, teachers, and social workers. The experts were inhabitants of large Russian cities (Moscow, Saint Petersburg, Novosibirsk, Smolensk, Omsk, Kazan, and Tyumen). The sample was formed using the "snowball" method. The respondents were asked about the special features of the national elderly education system as a potential object of management, current goals of elderly education management, and possible management factors.

To classify the organizational forms of the elderly education projects, the following attributes were used: self-identification (usually reflected in the name of educational projects); orientation (education, rehabilitation, leisure, etc.); period of training; training format; requirements for the teaching staff's qualifications; types of institutions as venues and participants of educational projects and events. The organizational forms of the elderly education projects implemented in Russia fall into four categories: clubs, lecture courses, educational courses and third age universities.

\section{RESULTS}

Among the factors exerting the most profound effect on the Russian system of elderly education are the non-formal nature of educational programs, insecure funding of projects and lack of outer influence that would integrate and coordinate the development process.

Currently, the alloy of the elderly education practices functions according to the principle of a social network (Ferguson, 2017). Network-based organization allows being independent from the external environment and developing sustainably. The nodes of the network structure are educational projects that raise funds independently, establish goals and objectives of their activities, as well as choose the optimal format for solving educational problems. At that, the forms of project implementation are rather diverse. 
Figure 1. Institutions implementing elderly education programs in Russia distributed by organizational forms of educational activities, 2019.

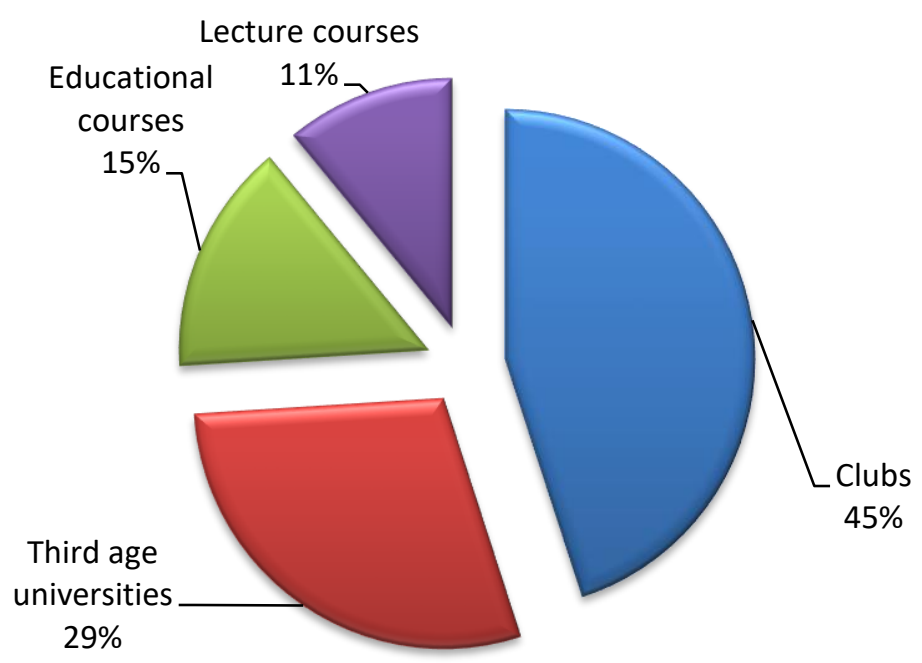

Figure 1 presents the share of each organizational form in the total number of institutions implementing elderly education programs in Russia in 2019. Let us briefly describe each of them.

Clubs. This is a fairly popular form of interaction between older people to spend leisure time together and meet various needs (including education). Typically, clubs are organized on the basis of social security institutions, cultural centers, and public organizations. At the same time, education services are rarely the main specialization of clubs. Educational programs (or even particular training events such as lectures, round-table discussions, and guided tours) are mostly episodic, of unspecified duration and organized according to the preferences of the club members.

Teacher responsibilities are taken on by employees of the institutions on the basis of which clubs operate, as well as by club members themselves. This is a rare occurrence to engage qualified specialists (doctors, psychologists, lowers and social workers), who are not usually professional teachers, in providing training. Classes are usually held in informal or semi-formal settings in the form of conversation, excursion, or consultation. Such freedom and flexibility in organizing training activities, as well as their informal nature fit well into the ideology of the club movement. Studying in a club weakens the psychological barriers that prevent the elderly from continuing their education. Here, studying represents a form of entertainment and leisure; however, clubs play a critical part in expanding the national elderly education network. They are agents for primary reintegration of senior citizens into the domain of education. Club study experience encourages individuals to continue their education through other organizational forms of training. It is typical of such clubs to hold entertainment events complemented by educational activities (round table discussions, lectures, seminars) and meetings with experts (the pension fund specialists, notaries, doctors, etc.) (Sorokin, 2011).

Lecture courses. According to this organizational form of educational activities, classes for the elderly are held periodically in the predominant form of lectures or, less frequently, in the form of seminars and round-table discussions. In Russia, lecture courses are mostly hosted by cultural and social security institutions. Professional teachers or experts with experience in lecturing are involved in the educational process. As a rule, lecture courses are not reduced to a specific focus area, and therefore, experts from different fields of knowledge and practitioners whose expertise is of interest for students are invited to conduct classes. However, there are lecture courses focused on a particular subject (general and local history, art, etc.). In this case, each lecture is a selfsufficient piece of information, which makes it easier for new students to join the educational 
process, and allows students to attend classes in a selective manner (according to their needs and interests). This organizational form is used if an educational institution aims to attract a broad audience and reach distant cities (Shkatova \& Saprykina, 2004).

Educational courses. The distinctive features of this form of the elderly education programs implementation are the concentration on one specific area (computer literacy, psychology, healthcare science, etc.), and that classes are designed to develop practical skills within a short time (short courses). Organization of educational courses is imposed on educational and cultural centers, whereas the teacher responsibilities are taken by their employees (professional teachers). Oftentimes, these organizations do not regard education for older adults as their main and only priority. Work with seniors mainly pursues educational goals (Voytovich, 2016). The specifics of educational courses allow students to acquire specialized knowledge, skills and abilities in a relatively short time. Therefore, such courses can be viewed as a promising basis for implementing vocational training and retraining programs for senior citizens, which may be in demand in the near future.

Third age universities. A widespread form of the educational process organization is third age universities (senior universities, universities of the golden age, higher public schools, folk faculties are included in the same category). Usually, their founders are educational or social security institutions. A significant number of third age universities in Russia are divisions of higher education institutions or cooperate with them. Founders usually opt for this organizational form if the institution's thrust is educational and teaching activities.

Third age universities demonstrate some attributes typical of higher educational institutions. In particular, in their structure there are faculties headed by deans, the study period is divided into semesters or sessions, student cards are used in some, etc. Students have the opportunity to attend several courses supervised by faculties. In the curriculum, theoretical disciplines prevail over practice-oriented courses. At the end of the study, students take a graduation test. There are a number of third age universities that succeeded in their mission and their experience and best practices can be of use when developing the elderly education system at large (Barabanov, 2007).

The research results show that the form in which a project is implemented is largely determined by the type of organization on the basis of which it operates (Table 1). As of 2019, the most common form of elderly education was third age universities ( $77 \%$ and $53 \%$ respectively). Nonprofit organizations, cultural institutions and authorities gave preference to educational courses (50\%, $43 \%$ and $50 \%$ respectively). The overwhelming majority of educational projects at social security institutions were implemented in the form of clubs. No authorities named lecture courses as their preferred format, unlike cultural institutions, which practiced it in $29 \%$ of cases.

Table 1. Organizational forms of senior citizens' educational activities according to types and forms of organizations.

\begin{tabular}{ccccc}
\hline \multirow{2}{*}{ Type of organization } & Clubs & $\begin{array}{c}\text { Lecture } \\
\text { courses }\end{array}$ & $\begin{array}{c}\text { Educational } \\
\text { courses }\end{array}$ & $\begin{array}{c}\text { Third age } \\
\text { universities }\end{array}$ \\
\cline { 2 - 5 } & 3 & 10 & 10 & 77 \\
Universities & 24 & 12 & 12 & 53 \\
The Russian society "Znanie" & 14 & 14 & 50 & 23 \\
Non-profit organizations & 10 & 29 & 43 & 19 \\
Cultural institutions & 72 & 9 & 8 & 11 \\
Social security institutions & 17 & 0 & 50 & 33 \\
Authorities & 50 & 17 & 33 & 0 \\
Other & & & & \\
\hline
\end{tabular}


The network structure of elderly education in Russia and the polymorphism of educational projects' formats predetermine the peculiarities of the management processes. To provide effective management, it is of high importance to establish goals and tasks. The avenues for the development of elderly education should be obviously synchronized with the overall situation in the country and the existing social problems. The expert survey indicated that in the Russian society there are a number of problems directly associated with older people being excluded from the educational space. Respondents highlighted several contradictions of a socio-economic and cultural nature that can be organized into three groups (or, in other words, three main challenges). Their occurrence according to the experts is given in figure 2 .

Figure 2. Results of the expert survey on challenges associated with the need to raise the educational level of the elderly

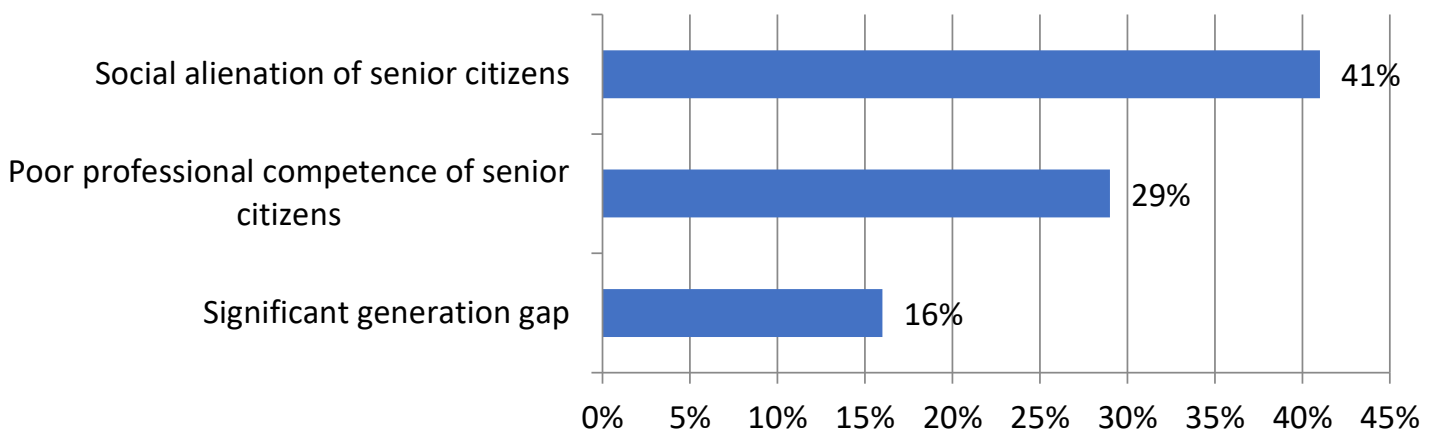

Let us elaborate on the challenges pointed out by the experts.

Social alienation. A great number of senior citizens in Russia are disintegrated from the social environment and experience considerable difficulties when handling even simple everyday tasks. Under these circumstances, any attempts to utilize the older generation resources for resolving social problems will turn out to be ineffective. Social adaptation refers to the adjustment of an individual (a group of individuals) to the social environment, which implies interaction of both parties and step-by-step coordination of their expectations (Kovaleva, 2003). In old age, the adaptive abilities of an individual are significantly reduced due to health and economic issues, as well as the declining number of social contacts. In Russia, social alienation of the elderly is also caused by the fact that institutional approaches to providing social support for seniors are obsolete and do not meet modern requirements.

Poor professional competence of senior citizens. In the context of population aging, there is an urgent need to exploit the residual working capacity of older adults. At the same time, the lack of up-to-date professional knowledge and skills prevents senior Russians from integrating into the production and economic sphere, increases their vulnerability in the labor market, and limits their employment opportunities to low-paid unqualified jobs (Ambarova \& Zborovsky, 2019).

Generation gap in the Russian society. Another urgent problem of the Russian society is to reduce the generation gap and establish intergenerational dialogue. Any strategies aimed at increasing social and economic activity of seniors but ignoring cross-generational issues will be ineffective, since in fact they will turn out to be attempts to aggressively integrate the elderly into an unfriendly environment. Such an approach will not only fail to achieve the stated goals, but will also exacerbate the already difficult relationships between different generations. The recent studies confirm that the problem of cross-generational communication is still relevant (Savinov, Bistyaykina and Solovyova, 2018).

Based on the revealed problems, it is possible to establish the main goals of the elderly education in Russia and, consequently, the social guidelines for managing it: to facilitate the social adaptation of older adults; to reduce the generation gap in society; and to integrate senior citizens 
into the production and economic sphere. Having studied the projects of non-formal education, we have found that all the contradictions typical of the Russian elderly education had ready-made solutions.

These are mechanisms that can significantly reduce the severity of the problems. For instance, the elderly education demonstrates a huge potential for improving social adaptation of the older generation. Educational programs for seniors can have both a direct effect on their adaptive abilities (through everyday life skills training) and an indirect effect, which consists in creating favorable conditions for the adaptation to social changes, the aging process and the old age (organization of leisure time, expanding the circle of friends, self-realization, etc.). Educational projects often cover various courses aimed at informing participants about the peculiarities of the youth's lifestyle and subculture, as well as programs focused on developing the elderly as subjects of intergenerational dialogue. It is also noteworthy that the elderly education system is capable of forming the space for intergenerational communication. Representative of various generations have an opportunity to get to know each other, learn from each other or gain knowledge in the same classroom. The projects of elderly education in Russia have experience, yet limited, in helping senior citizens with professional socialization. By attending specialized courses, older people successfully master new professions and acquire the knowledge necessary for employment. These factors confirm the expediency of using the resources of the national elderly education system in order to solve urgent problems and determine the importance of studying the elderly education system as an object of social management.

At the next step of the expert survey, the respondents were asked to name measures aimed at ensuring effective management of the elderly education in Russia. The respondents' answers are given in table 2.

Table 2. Measures for providing effective management of the national elderly education system in Russia.

\begin{tabular}{lcc}
\hline \multicolumn{1}{c}{ Measure } & Occurrence \\
\hline 1. Stable and targeted funding of educational projects & $65 \%$ \\
2. Focusing elderly education management on resolving relevant socio- & $42 \%$ \\
economic problems of the Russian society & $35 \%$ \\
3. Taking into account the specifics of the organization and implementation of & \\
educational programs for the older generation & $29 \%$ \\
4. Distributing the tasks of elderly education between various agents \\
(organizations, institutions, etc.)
\end{tabular}

Predictably, the respondents stressed the need for stable funding of educational projects (65\%) and taking into account the specifics of educational programs for the older generation (35\%). The experts' recommendations concerning the technologization of the management processes are of much greater interest for the development of the management mechanisms for the national elderly education system. For example, $42 \%$ of respondents underlined the importance of focusing management on solving urgent social problems; $29 \%$ noted that it was expedient to distribute the 
tasks of elderly education between various agents; and $25 \%$ of respondents named the necessity to apply the network approach when managing the Russian system of elderly education.

\section{DISCUSSION}

Based on the research results, we lay down a principle for differentiating the management functions of the elderly education system. Its main idea lies in increasing the efficiency through the distribution of particular educational tasks between various agents, where the objectives of the educational project fit into the general course of the parent organization (Bondaletov, 2016). For instance, courses focused on seniors' social adaptation are a right choice to be implemented on the basis of social security institutions. Hence, it is expedient to differentiate the current tasks of the elderly education system management and address them to agents according to their main social functions. The principle of distribution of the functions is presented in figure 3 .

Figure 3. Principle for distributing the functions of management of the elderly education system (graphical representation).

Goals of elderly education network management

Agents of elderly education

Organizational forms of educational projects

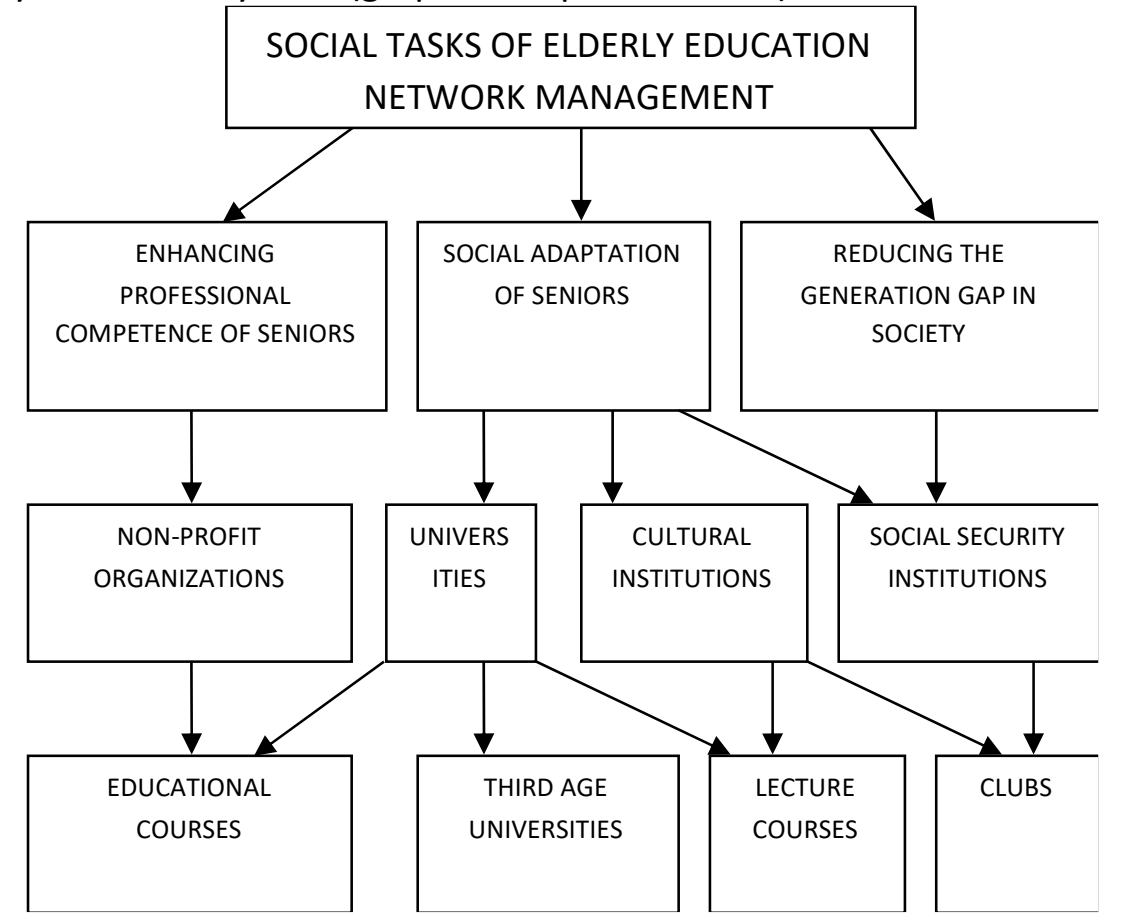

In figure 3, the goals of elderly education network management are integrated into blocks that were earlier referred to as social guidelines of elderly education management. Tasks for achieving them are distributed between the leading agents of elderly education (the most common founders of educational projects). There are no public authorities among the agents, since they promote elderly education mainly through sponsorship, so it seems not possible to define their role in the scheme of functions. The forms of educational projects were determined according to the compliance with the specific tasks of gerontology, their popularity with the educational agent, and the possibility of implementation. According to the principle, the functions of elderly education are differentiated in order to increase the efficiency of elderly education network management and the rational use of its resources.

\section{CONCLUSION}

Population ageing gives rise to a number of negative trends. The most effective mechanisms of adaptation to the ongoing changes are associated with the active integration of older people into all spheres of social life and an increase in their educational level. Non-formal educational projects 
can bear a significant part of the burden associated with training for the elderly. Elderly education projects in Russia are implemented in four forms. According to the research results, the form in which the project is implemented is largely determined by the type of organization on the basis of which it operates. The most common form of elderly education is the third age university $(77 \%$ are organized on the basis of universities, and $53 \%$ - on the basis of the Russian society "Znanie"). Nonprofit organizations, cultural institutions and authorities gave preference to the format "educational courses" (50\%, 43\% and 50\% respectively). At social security institutions, the overwhelming majority of educational projects were implemented in the form of clubs (up to $72 \%$ ). No authorities named lecture courses as their preferred format, unlike cultural institutions, which practiced it in $29 \%$ of cases.

The specifics of each form make it optimal for resolving a certain range of educational issues. The results of the present study have indicated that the focus area and the main social function of the project's parent organization had a significant impact on the effectiveness of educational programs. The efficiency of the centralized management of the elderly education network in Russia can be boosted through the distribution of management functions and the implementation of specific educational programs in the most suitable format. To do so, we have developed a principle for differentiating the functions of management of the elderly education system. The recommendations obtained through the expert survey can be used to optimize the mechanisms for managing the elderly education system.

Authors' Contributions: Matos, F. S.: conception and design, acquisition of data, analysis and interpretation of data, drafting the article, critical review of important intellectual content; Dias, A. F.: conception and design, acquisition of data, analysis and interpretation of data, drafting the article, critical review of important intellectual content; da Silva, I. P.: conception and design, acquisition of data, analysis and interpretation of data, drafting the article, critical review of important intellectual content. All authors have read and approved the final version of the manuscript.

Ethics Approval: Not applicable.

Acknowledgments: Not applicable.

\section{REFERENCES}

Ambarova, P. A., \& Zborovsky, G. E. (2019). Vocational education for people of the third age. The Education and Science Journal, 21(10), 59-88. https://doi.org/10.17853/1994-5639-2019-10-59-88

Barabanov, A. (2007). Pensioners will be attending lectures. Novoe Slovo - New Word, 7-8, 12-15.

Bondaletov, V. V. (2016). Fundamentals of public self-organization management: Problems of management and manageability. Proceedings of the Ivanovo Reading, 2(6), 12-18.

Chahrak, N., \& Ugryniuk, V. (2016). Ageing of the population in the developed countries: New challenges to education sector. Modern Science - Moderni Veda, 3(6), 86-96.

Eakin, T., \& Witten, T. M. (2018). Mechanics of population aging and survival. Biogerontology, 19(3-4), 251-269. https://doi.org/10.1007/s10522-018-9755-7

Elyutina, M. E., \& Chekanova, M. E. (2003). An elderly person in the educational space of modern society. Sociological Studies, 7, 43-90.

Ferguson, N. (2017). The square and the tower: Networks and power, from the Freemasons to Facebook. New York: Penguin Press.

Freydkina, E. M. (2017). Problems and trends in the development of elderly education in the Russian Federation. Human and Society in the System of Modern Scientific Paradigms, 1(3), 13-22.

Gelman, V. Ya. (2019). Continuous education and population ageing. Medical Education and Professional Development, 10(2-34), 40-51. doi:10.24411/2220-8453-2019-12001 
Kalyugina, S., Pianov, A., Tvaronaviciene, M., \& Sorokin, G. (2018). Depopulation and external migration as the institutional risks to personnel safety. Journal of Institutional Studies, 10(4), 125-144. https://doi.org/10.17835/2076$\underline{6297.2018 .10 .4 .125-144}$

Kononygina, T. M. (2006). Geragogy: A guide for those involved in training the elderly. Orel: Krasnaya Stroka.

Kovaleva, A. I. (2003). Social adaptation (pp. 17-18). In A. I. Ivanov (ed.). Sociological Encyclopedia (in 2 volumes). Vol. 1. Moscow: Mysl.

Lapshina, E. V. (2007). Modern goals in elderly education. New Knowledge, 4, 29-31.

Mosina, O. A., \& Gonezhuk, A. G. (2019). Modern trends in the development of elderly education in Russia. Modern High Technologies, 3-2, 284-288.

Russia in Numbers. (2019). Concise Statistical Yearbook. Moscow: Rosstat.

Savinov, L. I., Bistyaykina, D. A., \& Solovyova, T. V. (2018). The aging of the population and the formation of the population needs in social services. University Proceedings. Volga Region. Social Sciences. Sociology, 8(46), 98-106. https://doi.org/10.21685/2072-3016-2018-2-12

Shkatova, L. A. \& Saprykina, V. S. (2004, May 21-22). Forms of public education for the elderly. Elderly Education for New Russia, Moscow, Russia. Pp. 173-175.

Smirnova, T. V. (2008). Russian pensioners as a talent pool for small businesses. Monitoring of Public Opinion, 1, 121127.

Sorokin, G. (2020). Scenarios for the development of elderly education in Russia. Amazonia Investiga, 9(27), 478-484. https://doi.org/10.34069/Al/2020.27.03.51

Sorokin, G. G. (2011). Elderly education in Russia. Sociological analysis. Tyumen: TIU.

Taziev, S. F. (2015). Active life of the senior citizens through education. International Education Studies, 8(4), $134-142$. https://doi.org/10.5539/ies.v8n4p134

Voytovich, I. K. (2016). The third age in classical universities: International experience and Russian reality. Russian Journal of Multilingualism and Education, 8, 126-132.

Received: 31 July 2021 | Accepted: 22 September 2021 | Published: 29 December 2021

This is an Open Access article distributed under the terms of the Creative Commons Attribution License, which permits unrestricted use, distribution, and reproduction in any medium, provided the original work is properly cited. 